\title{
An Appraisal of Fluoride Distribution and Ionic Balance in Ground Water of Mundaragi Taluk, Gadag District, Karnataka, India: A Case Study
}

\author{
Aswini Arali'1, K. Lokesh'1, S. Manjappa², B. Suresh ${ }^{3}$ \\ ${ }^{1}$ Department of Civil Engineering, Tontadarya College of Engineering Gadag, Karnataka, India \\ ${ }^{2}$ Department of Chemistry, University BDT College of Engineering, Davangere, Karnataka, India \\ ${ }^{3}$ Department of Civil Engineering, Bapuji Institute of Engineering \& Technology, Davangere, Karnataka, India \\ Email: ashwiniarali@gmail.com,drvrlm@gmail.com,drsmubdtce@gmail.com,drbssmg@gmail.com
}

How to cite this paper: Arali, A., Lokesh, K., Manjappa, S., \& Suresh, B. (2021). An Appraisal of Fluoride Distribution and Ionic Balance in Ground Water of Mundaragi Taluk, Gadag District, Karnataka, India: A Case Study. Journal of Geoscience and Environment Protection, 9, 1-13. https://doi.org/10.4236/gep.2021.910001

Received: July 24, 2021

Accepted: October 15, 2021

Published: October 18, 2021

Copyright $\odot 2021$ by author(s) and Scientific Research Publishing Inc. This work is licensed under the Creative Commons Attribution International License (CC BY 4.0).

http://creativecommons.org/licenses/by/4.0/ (c) (i) Open Access

\begin{abstract}
A total, 25 different ground-water samples collected in Mundaragi taluk in of Gadag district, Karnataka, India to appraise the distribution of Fluoride. $\mathrm{pH}$ of collected groundwater is shown alkaline in nature and ranged between 7.18 and 9.32 with a mean value of 8.36. Fluoride content ranged between 0.86 to $4.63 \mathrm{mg} / \mathrm{L}$ in ground water samples, with minimum value $0.86 \mathrm{mg} / \mathrm{L}$ (MGK24) and maximum value $4.63 \mathrm{mg} / \mathrm{L}$ (MGK20). 48\% of samples indicated fluoride content below $1.4 \mathrm{mg} / \mathrm{L}$ and $32 \%$ samples indicated fluoride content in between 2.0 and $3.0 \mathrm{mg} / \mathrm{L}$. Followed by $8 \%$ of the samples showed fluoride content ranges above 3.1. The public from villagers have been used high fluoride-bearing groundwater for drinking prolonged period and suffering from fluorosis. Analytical values also predict that occurrence of minerals like apatite, fluorspar, topaz and mica gets processed naturally and releases fluoride into the lithosphere and percolates into ground water. The present study also helps find out a suitable adsorbent for removal of Fluoride in ground water. However, with respect to chemistry of water, the cation and anion balance of all the 25 groundwater samples were inside the recognized limit of $\pm 10 \%$. The fluoride content is maximum in $\mathrm{Na}^{+}-\mathrm{HCO}_{3}^{-}$type and low in $\mathrm{Ca}^{2+}-\mathrm{HCO}_{3}^{-}$type groundwater in the Mundaragi Taluk. Furthermore, $\mathrm{F}^{-}$ shown a significant positive correlation with $\mathrm{pH}, \mathrm{EC}, \mathrm{TDS}, \mathrm{Ca}^{2+}, \mathrm{HCO}_{3}^{-}$and negative correlation with $\mathrm{Mg}^{2+}$ and $\mathrm{NO}_{3}^{-}$, which shows that the alkaline condition of water is the key role for leachate forming of fluoride-bearing minerals. Gibbs chart shows all groundwater values are fall under dominance of rock weathering group with a tendency towards the evaporation dominance class. Hence, interaction of rock-water is the pioneer cause of raised fluoride
\end{abstract}


in the groundwater of the study area. Furthermore, the study showed no such substantial relation present between $\mathrm{F}^{-}$and $\mathrm{NO}_{3}^{-}$, these variables are further process to groundwater from different sources, $\mathrm{F}^{-}$from geological minerals and $\mathrm{NO}_{3}^{-}$from manmade activities.

\section{Keywords}

Fluoride, Cation, Anion Behaviour, Mundaragi, Karnataka, India

\section{Introduction}

Reasonable to maximum fluoride level in groundwater is published as one of the chief ecological issues in some of the countries (Buddharatna et al., 2014) and also aggressive, an estimated 0.2 billion people (Mishra et al., 2010). Roughly, in India, the extreme fluoride content in groundwater is reported in different districts covering Karnataka states in India, affecting 61 million individuals, along with 5.9 million children (Adimalla \& Venkatayogi, 2018). In general, fluoride is mixing in groundwater from fluorine enclosing minerals like fluorite, biotite, apatite, muscovite, hornblende, topaz, microlite, fluormica, amphibole, some micas and sedimentary rocks, particularly shale (Islam \& Patel, 2011; Ayoob \& Gupta 2006; Kanthe, 2014).

Apart from natural process, fluoride content may be distributed due to manmade activities like burning of coal, production industries like aluminium, steel, bricks, phosphate fertilizers comprise fluoride as an impurity and are entering as leachate down into the ground water (Nath \& Dutta 2010). The related human health hazards due to fluoride will roughly be classified as: dental, renal, reproductive, skeletal, neurological, developmental, endocrine and carcinogenic effects. Continuously drinking of fluoride contaminated water inhibits dental caries. Thus, the best pioneer step to control fluorosis is to confirm allowable fluoride content in drinking water. The WHO has suggested $1.5 \mathrm{mg} / \mathrm{L}$ as the maximum allowable limit of water (Kanthe, 2014; WHO, 2006). A survey report indicated that no appraisal have been conducted in the Mundaragi Taluk with respect to fluoride and fluorosis issues. Hence, chief objective of this work is to appraise the quality of ground water with special conditions to fluoride content.

\section{Materials and Methods}

\subsection{Study Area}

The study region Mundaragi taluk (Figure 1) is situated at $15.207^{\circ} \mathrm{N} 75.884^{\circ} \mathrm{E}$. Mundaragi is a Taluk and a municipality in Gadag district, Karnataka state of India. Mundargi is adjacent to two area headquarters, being $35 \mathrm{kms}$ (21 miles) from Gadag and $49 \mathrm{kms}$ (30 miles) from Koppal. It is 98 kilometers from Gajendragad. Most of the villages in the study region depend on the ground water as a source for drinking. 

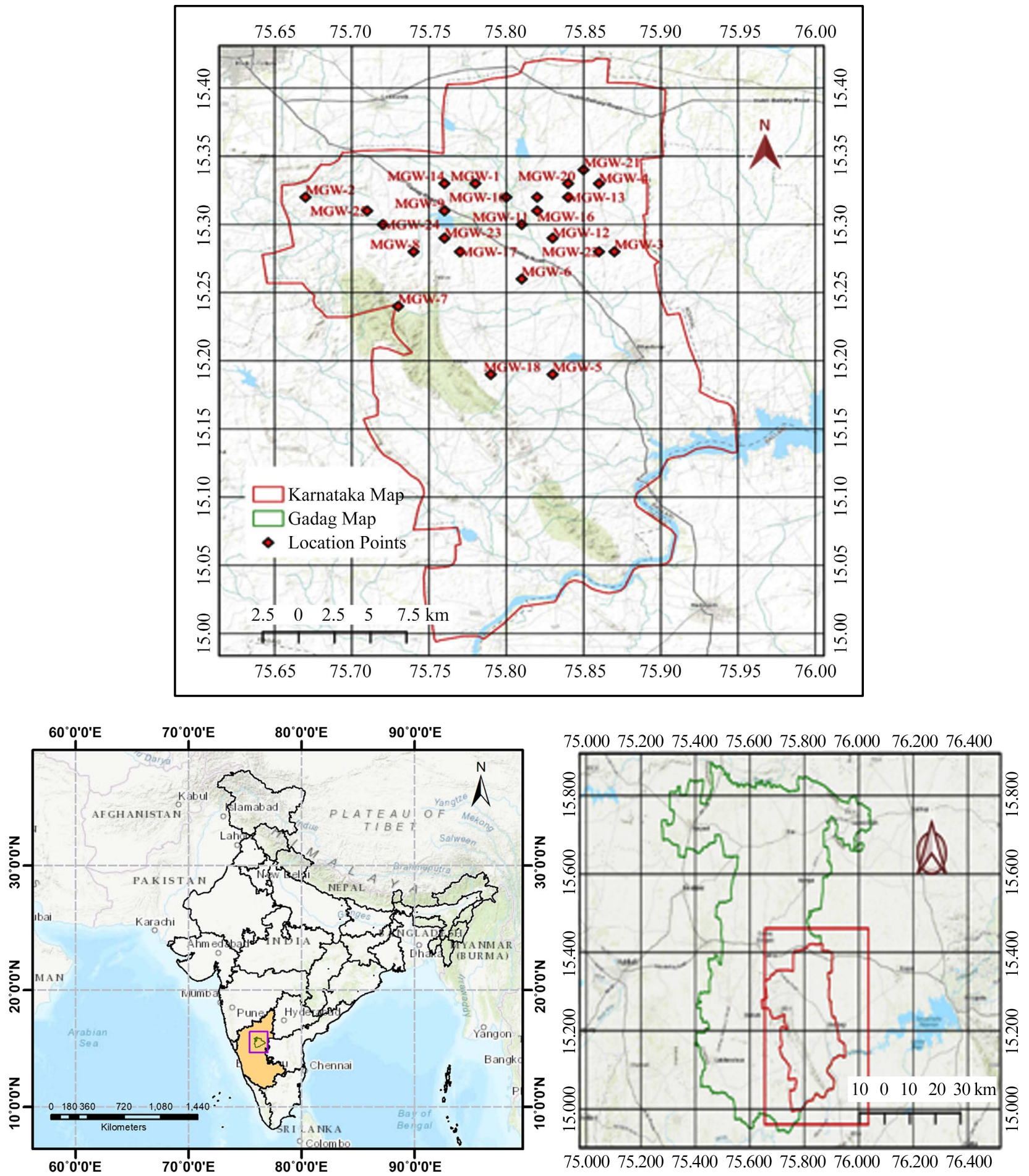

Figure 1. Location map of the groundwater samples from the Mundargi Taluk, Gadag district, Karnataka state, India.

\subsection{Water Sampling}

A total of 25 ground water samples collected in scientifically using clear acid rinsed polythene canes of one litre capacity from various bore wells at different sampling sites of Mundaragi Taluk. The ground water sampling was during the post monsoon session (October 2019 to January 2020). 


\subsection{Analysis}

Fluoride content was measured in ground water samples by adopting technique (APHA, 1998), Ion Selective Electrode method (Hatch, 101 with Orion electrode). Calcium $\left(\mathrm{Ca}^{2+}\right)$ and magnesium $\left(\mathrm{Mg}^{2+}\right)$ were analysed titrimetric method using EDTA, Sodium $\left(\mathrm{Na}^{+}\right)$and potassium $\left(\mathrm{K}^{+}\right)$contents by Flame photometer (Systronics, 148). Chloride $\left(\mathrm{Cl}^{-}\right)$was analysed by standard $\mathrm{AgNO}_{3}$ titration method. Bicarbonate $\left(\mathrm{HCO}_{3}^{-}\right)$and carbonate $\left(\mathrm{CO}_{3}^{2-}\right)$ determined by titration with $\mathrm{HCl}$. Sulfate $\left(\mathrm{SO}_{4}^{2-}\right)$ and nitrate $\left(\mathrm{NO}_{3}^{-}\right)$by using $\mathrm{UV}$-visible spectrophotometer (Shemadzhu 7000). Eventually, the value all chemical analyses results were calculated using formula (cations - anions)/(cations + anions) $\times 100$ ion-charge balance with cations $\left(\mathrm{Ca}^{2+}, \mathrm{Mg}^{2+}, \mathrm{Na}^{+}\right.$, and $\left.\mathrm{K}^{+}\right)$and anions $\left(\mathrm{HCO}_{3}^{-}, \mathrm{Cl}^{-}, \mathrm{SO}_{4}^{2-}\right.$, $\mathrm{NO}_{3}^{-}$, and $\mathrm{F}^{-}$). All the 25 groundwater samples are showed well within the accepted limit of $\pm 10 \%$ given by Domenico and Schwartz, 1990 .

\section{Results and Discussions}

Ground water samples from Mundaragi Taluk were clear no visible color, odour and turbidity during the study period. The fluoride content in ground water showed significantly in sampling locations of study areas (Figure 1). The fluoride content in ground water is given in Table 1 . The difference of fluoride content in ground water samples are given in Figure 2.

The fluoride content in the ground water samples indicated a define trends with respect to sampling locations of Mundaragi Taluk. Fluoride content ranged between 0.86 to $4.63 \mathrm{mg} / \mathrm{L}$ in ground water samples, with minimum value 0.86 $\mathrm{mg} / \mathrm{L}$ (MGK24) and maximum value $4.63 \mathrm{mg} / \mathrm{L}$ (MGK20). About $48 \%$ of samples indicated fluoride content below $1.4 \mathrm{mg} / \mathrm{L}$ and $32 \%$ samples indicated fluoride content is from 2.0 to $3.0 \mathrm{mg} / \mathrm{L}$. Followed by $8 \%$ of the samples showed fluoride content ranges above 3.1 (Figure 2). The results values are predicts; it is clear that the fluoride content in $32 \%$ of samples and $8 \%$ of samples are above the allowable limit ( $>1.5 \mathrm{mg} / \mathrm{L}, \mathrm{WHO}$ ) for drinking (Table 2).

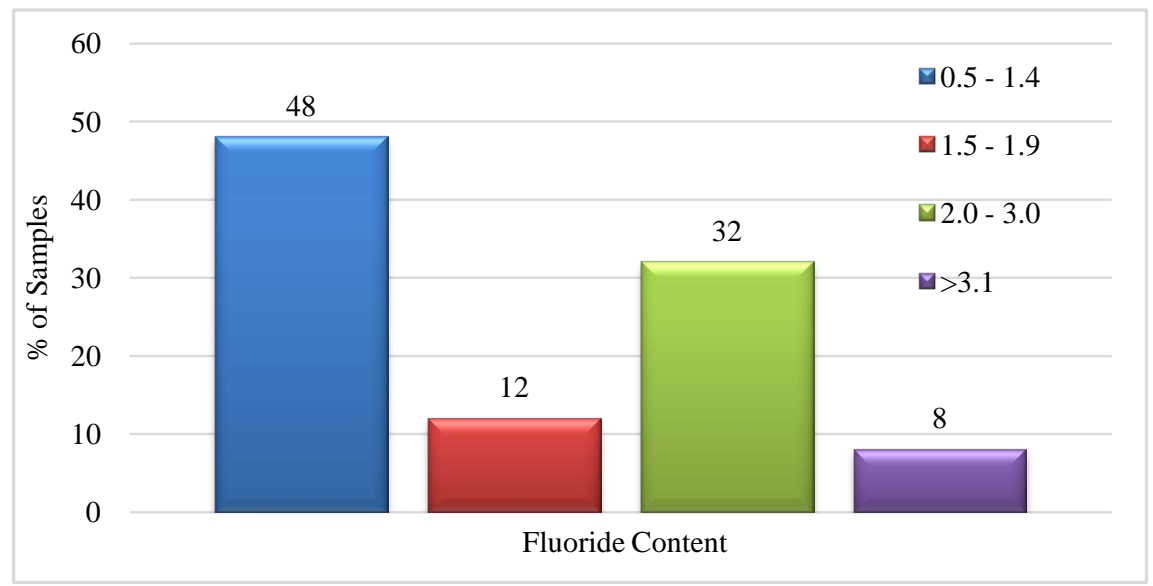

Figure 2. Classification of Fluoride in the groundwater of Mundaragi Talunk, (Gadag, Karnataka, India). 
A. Arali et al.

Table 1. Fluoride content and Ionic balance in sampling locations of Mundaragi Taluk (Gadag, Karnataka, India).

\begin{tabular}{|c|c|c|c|}
\hline Sl. No & Sampling Locations & Code & Fluoride $(\mathrm{mg} / \mathrm{L})$ \\
\hline 1 & Kadampur & MGK-1 & 0.98 \\
\hline 2 & Kadampur & MGK-2 & 0.98 \\
\hline 3 & Kadampur & MGK-3 & 0.98 \\
\hline 4 & Kadampur & MGK-4 & 0.97 \\
\hline 5 & New Dambal & MGK-5 & 1.03 \\
\hline 6 & New Dambal & MGK-6 & 1.02 \\
\hline 7 & New Dambal & MGK-7 & 1.28 \\
\hline 8 & New Dambal & MGK-8 & 1.10 \\
\hline 9 & Dambal & MGK-9 & 2.00 \\
\hline 10 & Dambal & MGK-10 & 1.33 \\
\hline 11 & Dambal & MGK-11 & 1.90 \\
\hline 12 & Dambal & MGK-12 & 1.78 \\
\hline 13 & Dambal & MGK-13 & 2.17 \\
\hline 14 & Narayanpur cross & MGK-14 & 3.14 \\
\hline 15 & Hirewaddatti-Mehundi road & MGK-15 & 2.14 \\
\hline 16 & Narayanpur & MGK-16 & 2.99 \\
\hline 17 & Narayanpur & MGK-17 & 2.53 \\
\hline 18 & Hirewaddatti math & MGK-18 & 2.33 \\
\hline 19 & Harogeri & MGK-19 & 2.14 \\
\hline 20 & Mushtikoppa cross & MGK-20 & 4.63 \\
\hline 21 & Basapur & MGK-21 & 1.55 \\
\hline 22 & Dambal beside lake & MGK-22 & 0.98 \\
\hline 23 & Dambal beside lake & MGK-23 & 1.00 \\
\hline 24 & Doni & MGK-24 & 0.86 \\
\hline \multirow[t]{3}{*}{25} & Doni & MGK-25 & 0.96 \\
\hline & & Maximum & 4.63 \\
\hline & & Minimum & 0.86 \\
\hline
\end{tabular}

Table 2. Ionic Balance, Cation and Anion data from different villages a Mundaragi Taluk (Gadag, Karnataka, India).

\begin{tabular}{ccccccccc}
\hline \multirow{2}{*}{ Code } & \multicolumn{9}{c}{ Anion } & \multicolumn{3}{c}{ Cation } \\
\cline { 2 - 9 } & $\mathrm{Ca}^{2+}$ & $\mathrm{Mg}^{2+}$ & $\mathrm{Cl}^{-}$ & $\mathrm{SO}_{4}^{2-}$ & $\mathrm{NO}_{3}$ & $\mathrm{HCO}_{3}$ & $\mathrm{Na}^{+}$ & $\mathrm{K}^{+}$ \\
\hline MGK-1 & 129.59 & 34.98 & 168.96 & 156.36 & 54.06 & 439.75 & 235.00 & 17.46 \\
MGK-2 & 124.93 & 30.44 & 67.88 & 63.83 & 49.75 & 430.42 & 238.99 & 13.41 \\
MGK-3 & 160.28 & 37.34 & 60.84 & 58.30 & 49.68 & 525.68 & 221.63 & 13.62 \\
MGK-4 & 141.17 & 39.84 & 80.15 & 67.12 & 39.71 & 454.78 & 236.61 & 19.00 \\
MGK-5 & 127.77 & 32.90 & 137.47 & 48.6 & 46.68 & 496.38 & 270.58 & 21.11 \\
MGK-6 & 152.86 & 39.75 & 83.85 & 37.54 & 39.64 & 424.35 & 371.75 & 17.17 \\
MGK-7 & 142.76 & 34.81 & 104.77 & 56.99 & 47.68 & 438.10 & 351.24 & 18.52 \\
MGK-8 & 123.05 & 34.86 & 47.42 & 37.46 & 40.00 & 440.58 & 223.71 & 23.88 \\
MGK-9 & 168.15 & 40.62 & 133.86 & 38.41 & 41.71 & 485.00 & 227.73 & 15.78 \\
MGK-10 & 188.34 & 40.87 & 135.21 & 71.88 & 40.50 & 466.49 & 225.20 & 18.52 \\
MGK-11 & 148.64 & 37.33 & 175.83 & 41.63 & 44.09 & 478.31 & 329.51 & 14.97 \\
\hline
\end{tabular}




\section{Continued}

\begin{tabular}{|c|c|c|c|c|c|c|c|c|}
\hline MGK-12 & 126.73 & 35.28 & 133.27 & 79.11 & 26.64 & 442.51 & 238.70 & 18.90 \\
\hline MGK-13 & 142.03 & 36.04 & 183.57 & 86.93 & 26.73 & 442.31 & 246.44 & 17.67 \\
\hline MGK-14 & 123.92 & 33.09 & 124.82 & 73.35 & 36.71 & 462.15 & 227.73 & 18.52 \\
\hline MGK-15 & 123.17 & 36.45 & 137.9 & 64.21 & 32.48 & 427.80 & 276.81 & 26.96 \\
\hline MGK-16 & 166.61 & 38.30 & 107.98 & 42.31 & 28.04 & 471.32 & 236.22 & 27.73 \\
\hline MGK-17 & 111.81 & 29.35 & 123.34 & 39.40 & 24.45 & 464.80 & 325.96 & 18.61 \\
\hline MGK-18 & 140.40 & 36.41 & 159.68 & 42.31 & 27.55 & 503.34 & 325.65 & 15.85 \\
\hline MGK-19 & 145.10 & 41.26 & 181.14 & 54.73 & 28.13 & 505.19 & 287.33 & 13.19 \\
\hline MGK-20 & 149.09 & 40.62 & 176.25 & 47.45 & 21.15 & 457.00 & 263.79 & 17.56 \\
\hline MGK-21 & 141.59 & 39.57 & 394.35 & 47.17 & 84.61 & 660.09 & 524.24 & 19.00 \\
\hline MGK-22 & 180.28 & 40.43 & 52.12 & 28.32 & 26.83 & 518.43 & 321.57 & 18.13 \\
\hline MGK-23 & 125.68 & 33.98 & 80.66 & 27.57 & 34.11 & 465.00 & 335.66 & 17.56 \\
\hline MGK-24 & 122.08 & 32.94 & 79.63 & 21.35 & 24.64 & 499.66 & 386.30 & 18.82 \\
\hline MGK-25 & 119.42 & 36.49 & 74.45 & 38.27 & 37.11 & 474.90 & 312.64 & 16.89 \\
\hline Maximum & 188.34 & 41.26 & 394.35 & 156.36 & 84.61 & 660.09 & 524.24 & 27.73 \\
\hline Minimum & 111.81 & 29.35 & 47.42 & 21.35 & 21.15 & 424.35 & 221.63 & 13.19 \\
\hline \multirow{2}{*}{ Code } & \multicolumn{8}{|c|}{ Ionic Balance } \\
\hline & \multicolumn{3}{|c|}{ Cation } & \multicolumn{2}{|c|}{ Anion } & \multicolumn{3}{|c|}{ Differences $\pm 10 \%$} \\
\hline MGK-1 & \multicolumn{3}{|c|}{17.90} & \multicolumn{2}{|l|}{17.29} & \multicolumn{3}{|c|}{1.73} \\
\hline MGK-2 & \multicolumn{3}{|c|}{12.98} & \multicolumn{2}{|l|}{13.97} & \multicolumn{3}{|c|}{-3.67} \\
\hline MGK-3 & \multicolumn{3}{|c|}{17.32} & \multicolumn{2}{|l|}{16.01} & \multicolumn{3}{|c|}{3.93} \\
\hline MGK-4 & \multicolumn{3}{|c|}{15.92} & \multicolumn{2}{|l|}{14.46} & \multicolumn{3}{|c|}{4.81} \\
\hline MGK-5 & \multicolumn{3}{|c|}{15.43} & \multicolumn{2}{|l|}{17.56} & \multicolumn{3}{|c|}{-6.46} \\
\hline MGK-6 & \multicolumn{3}{|c|}{14.40} & \multicolumn{2}{|l|}{13.45} & & 3.41 & \\
\hline MGK-7 & & 15.45 & & 14.83 & & & 2.05 & \\
\hline MGK-8 & & 13.79 & & 12.81 & & & 3.68 & \\
\hline MGK-9 & & 14.90 & & 16.38 & & & -4.73 & \\
\hline MGK-10 & & 16.87 & & 17.00 & & & -0.38 & \\
\hline MGK-11 & & 16.75 & & 17.5 & & & -2.19 & \\
\hline MGK-12 & & 16.66 & & 15.06 & & & 5.04 & \\
\hline MGK-13 & & 18.18 & & 16.66 & & & 4.36 & \\
\hline MGK-14 & & 16.82 & & 15.43 & & & 4.31 & \\
\hline MGK-15 & & 16.06 & & 15.00 & & & 3.41 & \\
\hline MGK-16 & & 15.07 & & 15.12 & & & -0.17 & \\
\hline MGK-17 & & 14.71 & & 15.24 & & & -1.77 & \\
\hline MGK-18 & & 15.6 & & 17.05 & & & -4.44 & \\
\hline MGK-19 & & 16.17 & & 17.75 & & & -4.66 & \\
\hline MGK-20 & & 18.10 & & 16.55 & & & 4.47 & \\
\hline MGK-21 & & 22.49 & & 24.95 & & & -5.19 & \\
\hline MGK-22 & & 15.27 & & 14.03 & & & 4.23 & \\
\hline MGK-23 & & 13.96 & & 13.83 & & & 0.47 & \\
\hline MGK-24 & & 17.9 & & 17.29 & & & 1.73 & \\
\hline MGK-25 & & 12.98 & & 13.97 & & & -3.67 & \\
\hline Maximum & & 22.49 & & 24.95 & & & 5.04 & \\
\hline Minimum & & 12.98 & & 12.81 & & & -6.46 & \\
\hline
\end{tabular}


As per the BIS, 2012 standard, the allowable and maximum permissible level of fluoride in drinking water is ranged between 0.6 and $1.2 \mathrm{mg} / \mathrm{L}$. If fluoride content less than $0.6 \mathrm{mg} / \mathrm{L}$ affect dental caries, while more than $1.2 \mathrm{mg} / \mathrm{L}$ cause fluorosis. It is reported that the fluoride content of groundwater during the study period is 4.63 is more than $1.2 \mathrm{mg} / \mathrm{L}$.

\subsection{Correlation of Fluoride with Other Variables}

To know the correlation with fluoride and chemical variables, correlation graphs gives important correlation and also support to understand the monitoring factors and its activity with fluoride content in the groundwater (Wang et al., 2019). A moderate positive correlation is noticed fluoride with $\mathrm{pH}$ (Figure 3(a)) which predicts that the maximum alkaline condition of water increases the enhancement of fluoride content and normally affects the content of fluoride in the groundwater (Ali Chandio et al., 2015). A significant positive relationship is identified fluoride with bicarbonate (Figure $3(\mathrm{~b})$ ) and also with sodium (Figure $3(\mathrm{c})$ ), which predicts that the alkaline ecological condition supports and controls chemical process to mix with fluoride and bleached with the fluoride containing minerals in the groundwater in the study area (Ali Chandio et al., 2015; Li et al., 2014; Subba Rao et al., 2017). Moreover, as predicted in Figure 3(d), the correlation fluoride with calcium, the values are clearly shows that the occurrence of maximum content of calcium will support less in fluoride content in the groundwater. It is indicated that the chief role of surface runoff is a main process for enrichment of fluoride in groundwater (Ali Chandio et al., 2015; Narsimha \& Sudarshan, 2018; Li et al., 2014).

A number of research works have reported that the positive relationships between fluoride with $\mathrm{Na}^{+}, \mathrm{pH}$ and bicarbonate and normally enhances the fluoride content in groundwater but vice versa with $\mathrm{Ca}^{2+}$, which predicts the content in fluorite soaked groundwater (Wang et al., 2019; Adimalla et al., 2018). However, Figure 3(e) depicts that the maximum content of EC and TDS is also connected with more fluoride content and the related publications done at various locations and regions (Saxena \& Ahmed, 2001; Jabeen et al., 2016; Adimalla et al., 2018; Subbarao et al., 2014; Sami et al., 2016; Wang et al., 2019; Anim-Gyampo et al., 2018; Narsimha \& Sudarshan, 2013). Furthermore, EC and TDS relationship with fluoride is not that much effect as high as other variables during the study period, which reveals that a maximum attraction of fluoride with $\mathrm{pH}$ and bicarbonate compared with EC and TDS. The present study reveals that, no significant correlation was found between fluoride and $\mathrm{SO}_{4}^{2-}, \mathrm{Cl}^{-}$, and $\mathrm{K}^{+}$but negative correlation with $\mathrm{Mg}^{2+}$. The analytical values show that the ionic composition added into groundwater is not key sources. Furthermore, it is showed that no noticeable relation exists $\mathrm{F}^{-}$with $\mathrm{NO}_{3}^{-}$(Figure $3(\mathrm{f})$ ) as these variables are mix with groundwater from different sources, $\mathrm{F}^{-}$from geological minerals and $\mathrm{NO}_{3}^{-}$from manmade activities. 
A. Arali et al.

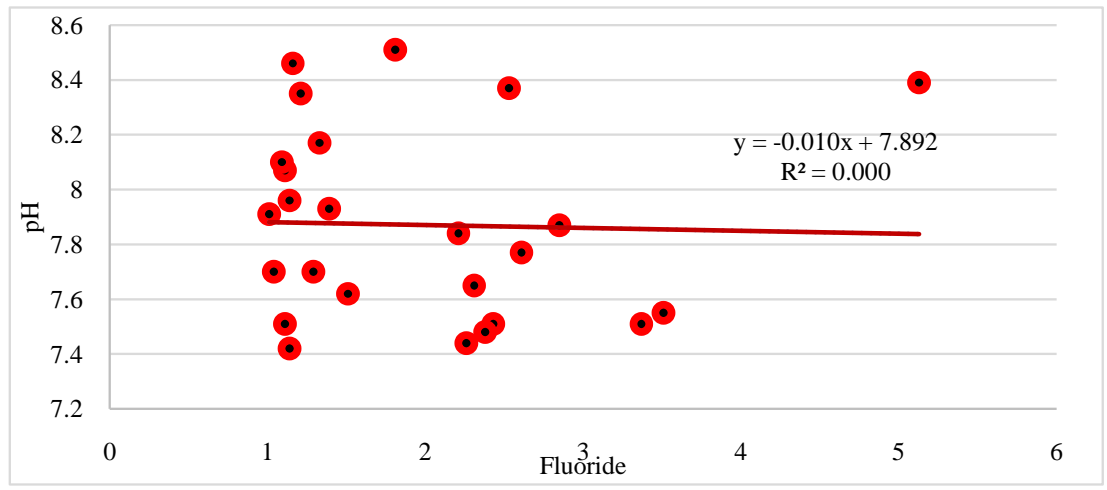

(a)

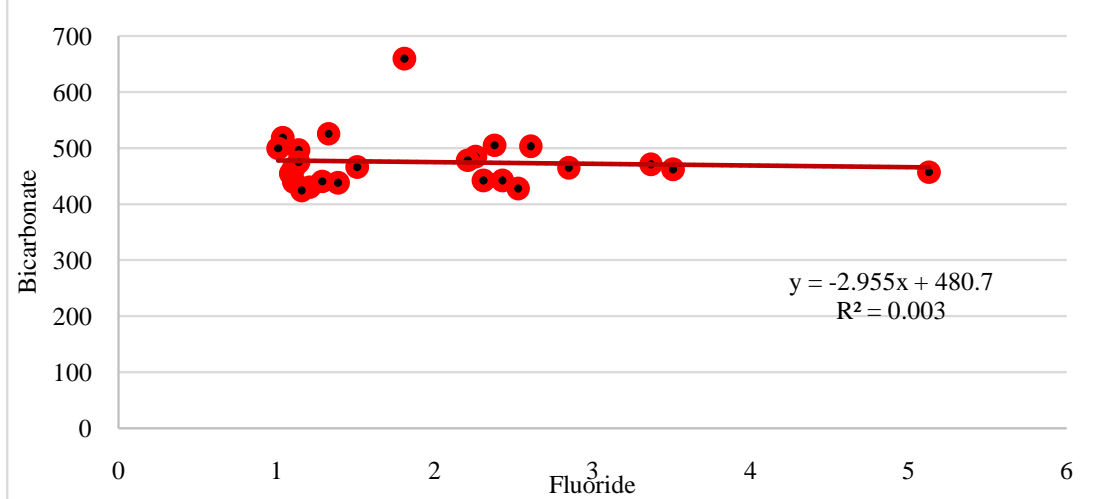

(b)

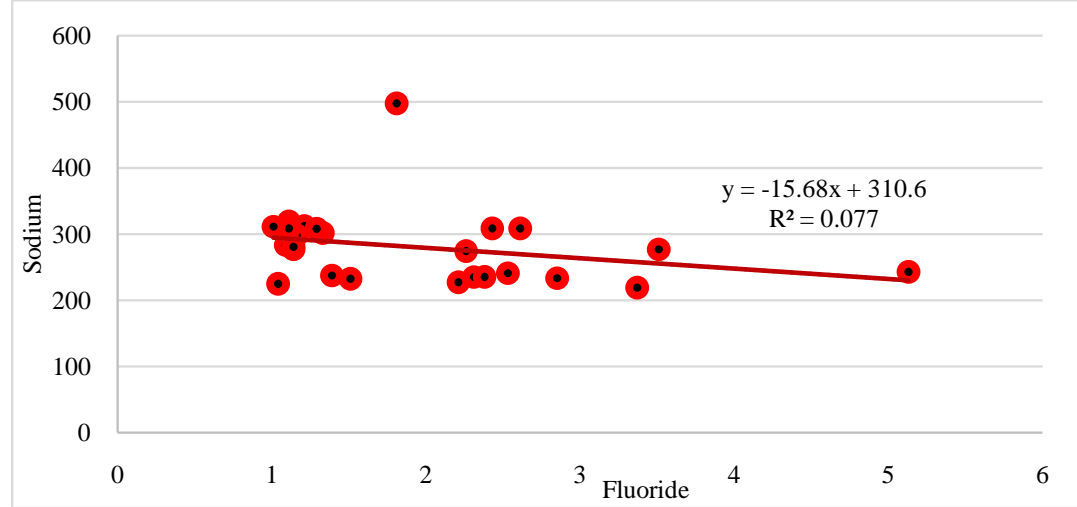

(c)

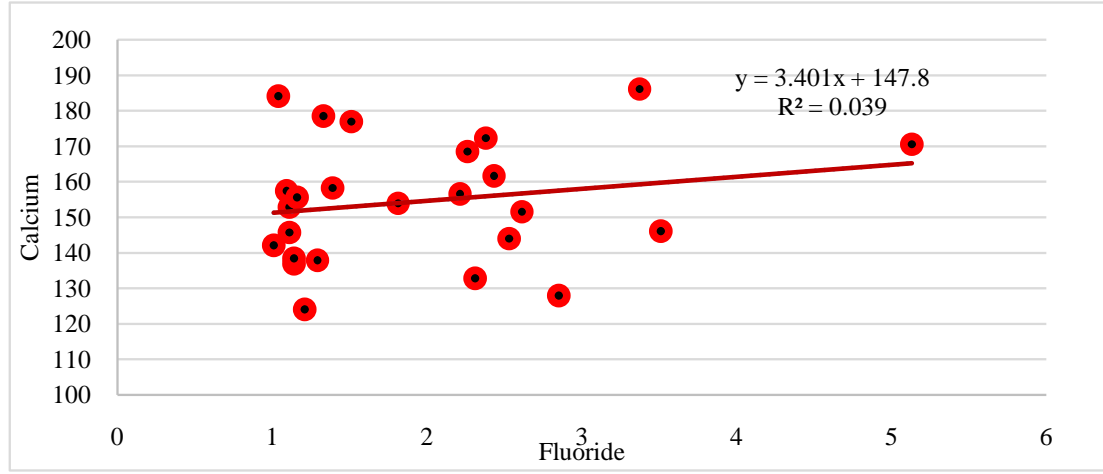

(d) 


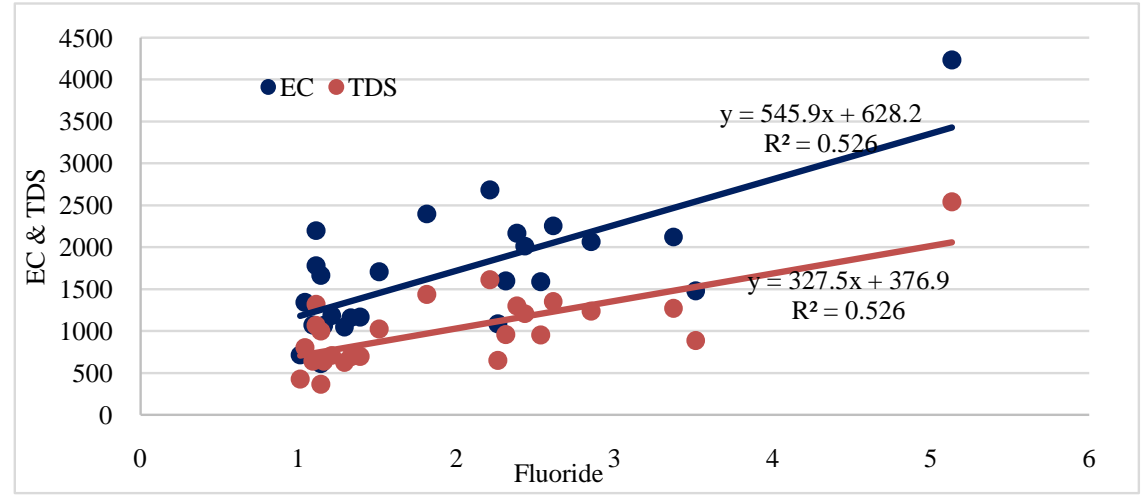

(e)

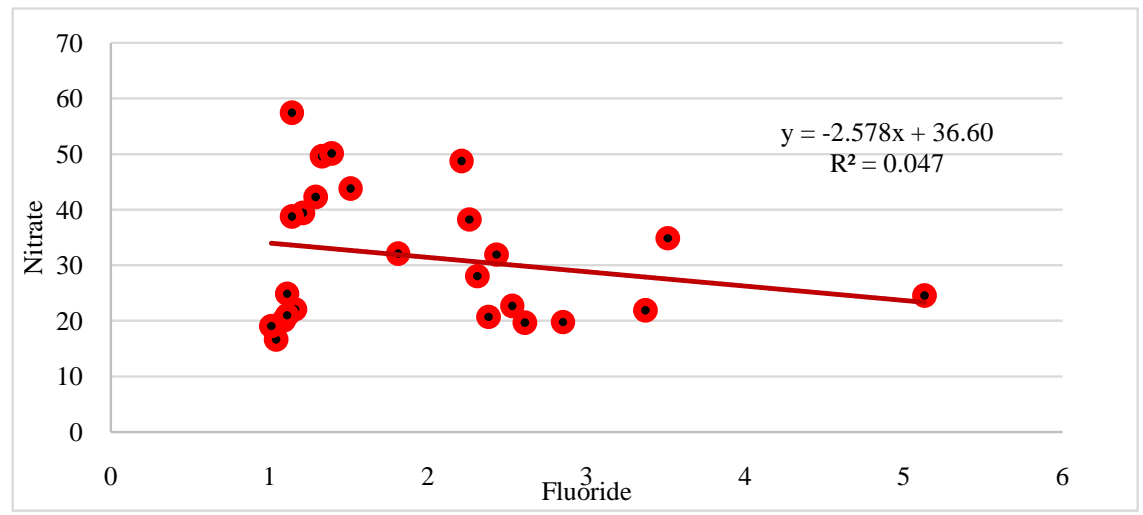

(f)

Figure 3. (a) Correlation between a fluoride and $\mathrm{pH}$; (b) Correlation between a fluoride and $\mathrm{HCO}_{3}$; (c) Correlation between a fluoride and $\mathrm{Na}^{+}$; (d) Correlation between a fluoride and $\mathrm{Ca}^{+}$; (e) Correlation between a fluoride and EC and TDS; (f) Correlation between a fluoride and $\mathrm{No}_{3}$.

\subsection{Process of Rock Dominance}

Gibbs diagram (Figure 4) shows that the selected groundwater samples are fall under the rock dominance, which normally generates from the weathering rocks present in beds and also chief process to enhance the fluoride content in groundwater (Sami et al., 2016; Adimalla \& Wu, 2019). Analytical results of the groundwater samples also indicates water chemistry and end with evaporation process and none of the sampling location present in the rainfall dominance (Figure 4). Results indicates, fluoride content enters through leachate with typically comes from rocks like igneous and sedimentary at different layers of the lithosphere also presence of fluoride behaviour minerals (Kumar et al., 2014; Narsimha \& Sudarshan 2013, Jabeen et al., 2016).

Similar observations found using the Gibbs chart by Gibbs (1970) and other at coastal region of Andhra Pradesh, India (Subba Rao et al., 2017); Worldwide contamination of water by fluoride (Ali et al., 2016); groundwater and associated risk in Vaniyar River basin, Dharmapuri district, Tamil Nadu, India (Jagadeshan et al., 2015); groundwater in parts of eastern India (Patel et al., 2014) and Chimakurthy pluton, Prakasam District, Andhra Pradesh (Reddy et al., 2016) 

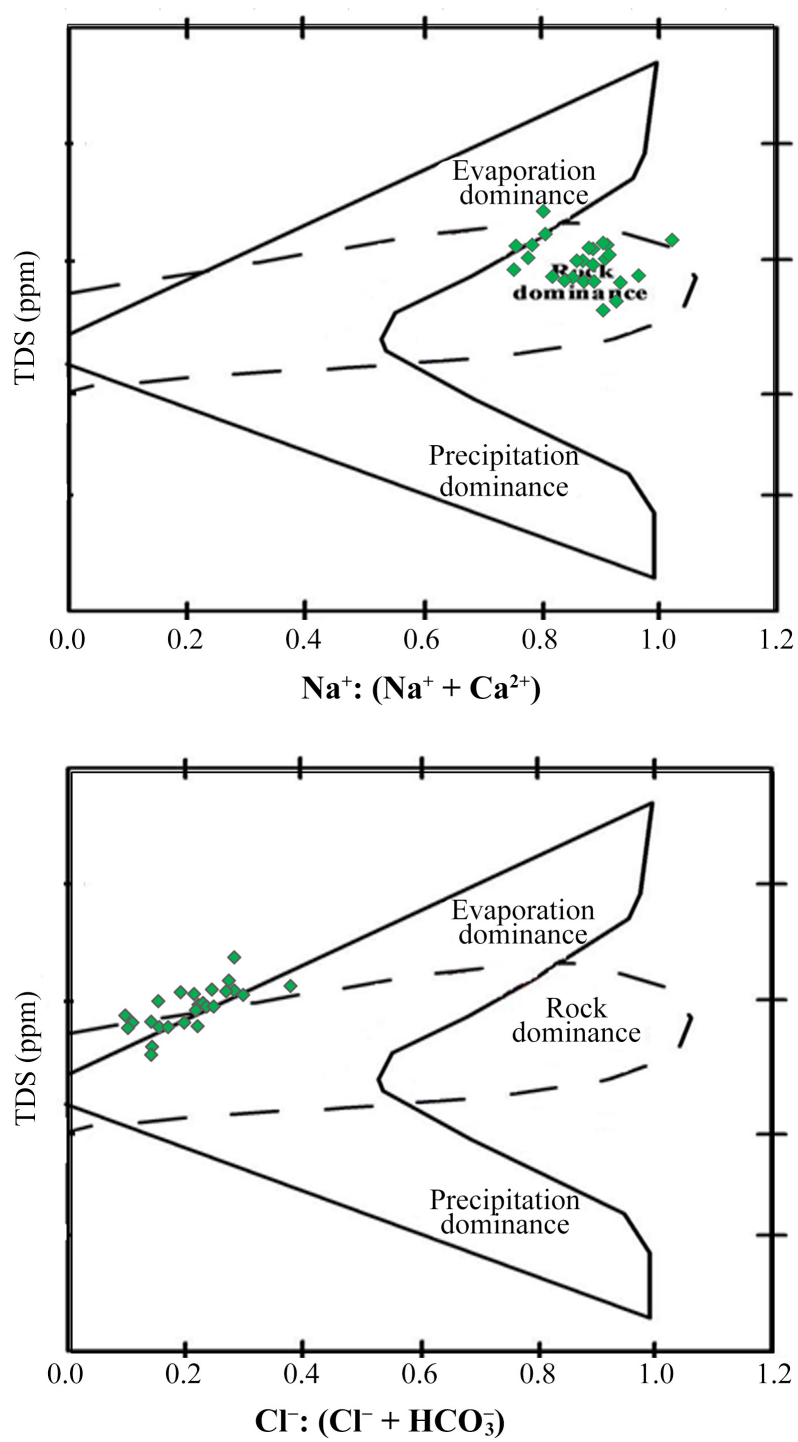

Figure 4. Gibbs diagram, chemistry of groundwater samples from Mundaragi Taluk (Gadag, Karnataka, India).

also agreement with to the present study found that fluoride content is related rock dominance plots in Gibbs chart. Similarly, it is also appreciated by the researchers is negative correlation between fluoride and nitrate also predicts fluoride from interaction of rocks not by the manmade activities. Hence, present study reveals that, in the some of the locations requires some treatment for fluoride. The "Nalgonda" and "activated alumina" techniques are the most commonly used defluoridation methods of drinking water. But, a suitable, effective, eco-friendly and cost effective, awareness is given in people regarding fluorosis. The present study also helps find out suitable adsorbent for removal of Fluoride in ground water.

\section{Conclusion}

Appraisal of Fluoride distribution and controlling factors of Ionic Balance in 
Ground water of Mundaragi Taluk, Gadag District, and Karnataka, India are reported the conclusions.

1) The fluoride contents range between 0.86 to $4.63 \mathrm{mg} / \mathrm{L}$ in ground water samples, with the lowest value $0.86 \mathrm{mg} / \mathrm{L}$ (MGK24) and maximum value 4.63 $\mathrm{mg} / \mathrm{L}$ (MGK20).

2) $32 \%$ samples indicated fluoride content between 2.0 to $3.0 \mathrm{mg} / \mathrm{L}$. Followed by $8 \%$ of the samples showed fluoride content ranges above 3.1 are crossed the suggested maximum limit by WHO and by BIS.

3) Rock-water interaction, leachate formation in aquifer, and freeing up of ionic minerals have affected the ionic condition of the water. Hence, the chief cause for maximum fluoride in the study area and during the study period may be due to reaction between rock and water, deficiency of calcium, and alkaline condition of water.

4) The excess of fluoride occurs in water, then water to be treated with de-fluoridation technique. The technology that is adopted for treatment of fluoride depends on the presence of fluoride content in water and the amount of fluoride to be removed.

5) The purpose of this study was to appraise the occurrence and distribution of fluoride contents and ionic balance in the groundwater for human consumption in twenty different localities of Mundaragi Taluk, Gadag District to understand before COVID-19 to establish the health hazard due to fluoride and ions present due to geological changes.

6) Proper treatment approaches are recommended in some of the locations crossed the permissible limit for drinking purposes of the region along with different households.

\section{Acknowledgements}

The authors are highly thankful to the Editors and anonymous reviewers for their comprehensive observations and suggestions which significantly helped us to improve the quality of the manuscript. Authors also thank editors to publish our paper in esteemed journal.

\section{Conflicts of Interest}

The authors declare no conflicts of interest regarding the publication of this paper.

\section{References}

Adimalla, N., \& Venkatayogi, S. (2018). Geochemical Characterization and Evaluation of Groundwater Suitability for Domestic and Agricultural Utility in Semi-Arid Region of Basara, Telangana State, South India. Applied Water Science, 8, Article No. 44. https://doi.org/10.1007/s13201-018-0682-1

Adimalla, N., \& Wu, J. (2019). Groundwater Quality and Associated Health Risks in a Semi-Arid Region of South India: Implication to Sustainable Groundwater Management. Human and Ecological Risk Assessment: An International Journal, 7, 1-26. 
https://doi.org/10.1080/10807039.2018.1546550

Adimalla, N., Vasa, S. K., \& Li, P. (2018). Evaluation of Groundwater Quality, Peddavagu in Central Telangana (PCT), South India: An Insight of Controlling Factors of Fuoride Enrichment. Modeling Earth Systems and Environment, 4, 841-852. https://doi.org/10.1007/s40808-018-0443-z

Ali Chandio, T., Nasiruddin Khan, M., \& Sarwar, A. (2015). Fluoride Estimation and Its Correlation with Other Physicochemical Parameters in Drinking Water of Some Areas of Balochistan, Pakistan. Environmental Monitoring and Assessment, 187, Article No. 531. https://doi.org/10.1007/s10661-015-4753-6

Ali, S., Thakur, S. K., Sarkar, A., \& Shekhar, S. (2016). Worldwide Contamination of Water by Fuoride. Environmental Chemistry Letters, 14, 291-315. https://doi.org/10.1007/s10311-016-0563-5

Anim-Gyampo, M., Anornu, G. K., Appiah Adjei, E. K., \& Agodzo, S. K. (2018). Hydrogeochemical Evolution and Quality Assessment of Groundwater within the Atankwidi Basin: The Case of Northeastern Ghana. Arabian Journal of Geosciences, 11, Article No. 439. https://doi.org/10.1007/s12517-018-3753-6

APHA (American Public Health Association) (1998). Standard Methods for the Examination of Water and Wastewater. American Public Health Association, American Water Works Association and Water Environmental Federation.

Ayoob, S., \& Gupta, A. K. (2006). Fluoride in Drinking Water: A Review on the Status and Stress Effects. Critical Reviews in Environmental Science and Technology, 36, 433-487. https://doi.org/10.1080/10643380600678112

Buddharatna, J., Godboley, P., \& Nagarnaik, B. (2014). Exposure of Fluoride Contamination to Ground water and Removal by Adsorption Method: A Review (pp. 304-309). Indian Water Works Association.

Domenico, P. A., \& Schwartz, F. W. (1990). Physical and Chemical Hydrogeology (pp. 410-420). Wiley.

Gibbs, R. J. (1970). Mechanisms Controlling World's Water Chemistry. Science, 170, 1088-1090. https://doi.org/10.1126/science.170.3962.1088

Islam, M., \& Patel, R. K. (2011). Thermal Activation of Basic Oxygen Furnace Slag and Evaluation of Its Fluoride Removal Efficiency. Chemical Engineering Journal, 169, 68-77. https://doi.org/10.1016/j.cej.2011.02.054

Jabeen, U., Fahmid, S., Zameer, T., \& Qureshi, S (2016). Determination of Fluoride Concentration in Drinking Water and its Comparison with Mineral Water Samples in Quetta. Pakistan Journal of Weed Science Research, 4, 81-84.

Jagadeshan, G., Kalpana, L., \& Elango, L. (2015). Major Ion Signatures for Identification of Geochemical Reactions Responsible for Release of Fluoride from Geogenic Sources to Groundwater and Associated Risk in Vaniyar River Basin, Dharmapuri District, Tamil Nadu, India. Environmental Earth Sciences, 74, 2439-2450. https://doi.org/10.1007/s12665-015-4250-9

Kanthe, V. N. (2014). Water Quality Assessment and Health Survey in Dhundi Village-A Case Study. International Journal of Research in Advent Technology, 2, 38-42.

Kumar, P. J. S., Jegathambal, P., \& James, E. J. (2014). Factors Influencing the High Fuoride Concentration in Groundwater of Vellore District, South India. Environmental Earth Sciences, 72, 2437-2446.

https://doi.org/10.1007/s12665-014-3152-6

Li, P. Y., Qian, H., Wu, J. H., Chen, J., Zhang, Y. Q., \& Zhang, H. B. (2014). Occurrence 
and Hydrogeochemistry of Fluoride in Alluvial Aquifer of Weihe River, China. Environmental Earth Sciences, 71, 3133-3145. https://doi.org/10.1007/s12665-013-2691-6

Mishra, A., Bhatt, V. D., Sevak, N., Shah, P., Patel, K., \& Patel, C. (2010). Comparative Study of PhysicoChemical and Microbial Parameters on Lotic and Ground-Waters in Selected Outlying Areas of Central Gujarat, Journal of Chemical and Pharmaceutical Research, 2, 174-177.

Narsimha, A., \& Sudarshan, V. (2013). Hydro-Geochemistry of Ground Water in Basara Area, Adilabad District, Andhra Pradesh, India. Journal of Applied Geochemistry, 15, 224-237.

Narsimha, A., \& Sudarshan, V. (2018). Drinking Water Pollution with Respective of Fuoride in the Semi-Arid Region of Basara, Nirmal District, Telangana State, India. Data Brief, 16, 752-757. https://doi.org/10.1016/j.dib.2017.11.087

Nath, S. K., \& Dutta, R. K. (2010). Fluoride Removal from Water Using Crushed Limestone. Indian Journal Chemical Technology, 17, 120-125.

Patel, S. C., Khalkho, R., Patel, S. K., Sheikh, J. M., Behera, D., Chaudhari, S., \& Prabhakar, N. (2014). Fluoride Contamination of Groundwater in Parts of Eastern India and a Preliminary Experimental Study of Fluoride Adsorption by Natural Haematite Iron Ore and Synthetic Magnetite. Environmental Earth Sciences, 72, 2033-2049. https://doi.org/10.1007/s12665-014-3112-1

Reddy, A. G. S., Reddy, D. V., \& Sudheer Kumar, M. (2016). Hydrogeochemical Processes of Fuoride Enrichment in Chimakurthy Pluton, Prakasam District, Andhra Pradesh, India. Environmental Earth Sciences, 75, Article Number: 663.

https://doi.org/10.1007/s12665-016-5478-8

Sami, H., Vichayanrat, T., \& Satitvipawee, P. (2016). Caries with Dental Fluorosis and Oral Health Behaviour Among 12-Year School Children in Moderate-Fluoride Drinking Water Community in Quetta, Pakistan. Journal of College of Physicians and Surgeons Pakistan, 26, 744-747.

Saxena, V. K., \& Ahmed, S. (2001). Dissolution of Fluoride in Groundwater: A Water-Rock Interaction Study. Environmental Geology, 40, 1084-1087. https://doi.org/10.1007/s002540100290

Subba Rao, N., Surya Rao, P., Dinakar, A., Nageswara Rao, P. V., \& Marghade, D. (2017). Fluoride Occurrence in the Groundwater in a Coastal Region of Andhra Pradesh, India. Applied Water Science, 7, 1467-1478. https://doi.org/10.1007/s13201-015-0338-3

Subbarao, N., Vidyasagar, G., Surya Rao, P., \& Bhanumurthy, P. (2014). Assessment of Hydrogeochemical Processes in a Coastal Region: Application of Multivariate Statistical Model. Journal of the Geological Society of India, 84, 494-500.

https://doi.org/10.1007/s12594-014-0155-6

Wang, Y., Yu, R., \& Zhu, G. (2019). Evaluation of Physicochemical Characteristics in Drinking Water Sources Emphasized on Fluoride: A Case Study of Yancheng, China. International Journal of Environmental Research and Public Health, 16, Article No. 1030. https://doi.org/10.3390/ijerph16061030

WHO (World Health Organization) (2006). Guidelines for Drinking-Water Quality. Recommendations: Addendum (3rd ed., Vol. 1). World Health Organization. 